\title{
Maja Smrekar’s Biopolitical Manifesto from a Philosophical Perspective
}

Abstract: With her series K-9_topology, Maja Smrekar is challenging anthropocentrism by linking biology and culture, in particular addressing interaction between human and animal species. The artist builds upon the recent scientific findings that it is not only the dog species that has been domesticated; the domestication that took place during evolution is to be considered mutual. Not only has the dog been mastered by the human, but dogs have had an active role in "using" the human species for a more comfortable survival as well. Both species coexist. In the project Ecce Canis Maja Smrekar built upon the sense of smell as an interface used to trigger the emotional connection between the species.

Hybrid Family is another project in the K-9_topology series. In this performance Smrekar nurtured a puppy. By submitting herself to two and a half months of physiological training, she achieved milk production in her breasts. The artist refers to this process as to the process of becoming, of becoming-animal, becoming-woman and becoming $\mathrm{m}$ (Other). She is deeply rooted in her own experience at the beginning of the $3^{\text {rd }}$ millennium, when "liberal capitalism finally struck hard into the newborn Slovenian economy", as she writes in her blog: her parents lost their business, house, cars, forests, meadows and vineyards, and her father committed suicide. She finds her own way of resisting, which is in submitting herself

\footnotetext{
${ }^{1}$ Dr. Polona Tratnik is Dean of Alma Mater Europaea - Institutum Studiorum Humanitatis, Ljubljana Graduate School of the Humanities. E-mail: polona.tratnik@almamater.si.
} 
to a "dog-human kinship relationship as a radical intimate action of 'returning home'”.

In the present paper, the process of becoming mother is analysed in relation to the process of becoming animal. Furthermore, the process of becoming ( $\mathrm{m}$ ) Other is particularly examined with reference to the mother-and-child unity, applying the Umwelt notion and a Hegelian, existentialist feminist and post-structuralist discussion of identity and difference. The process of becoming (m)Other is finally examined as a biopolitical statement or intervention with the investment of the artist's body. Its purpose is to re-gain the position of power, i.e. to perform an act of resistance to bio-power on and through bodies.

Keywords: biopolitics, Other, bio art, Maja Smrekar, bio-power, performance art, K-9_topology, Hybrid Family

UDK 7:606

\section{Biopolitični manifest Maje Smrekar s filozofske perspektive}

Izvleček: S svojo serijo K-9_topologija, Maja Smrekar izziva atropocentrizem s povezovanjem biologije in kulture, še posebej pa naslavlja interakcijo med človeškimi in živalskimi vrstami. Umetnica gradi na najnovejših znanstvenih dognanjih, da ni samo pasja vrsta tista, ki je bila udomačena; udomačitev, ki se je odvijala med evolucijo, se mora smatrati za obojestransko. Niso samo psom zagospodarili ljudje, ampak so tudi psi imeli aktivno vlogo pri "uporabi" človeške vrste za svoje bolj udobno preživetje. Obe vrsti sobivata. Pri projektu Ecce Canis je Maja Smrekar gradila na čutu za voh kot vmesniku, ki se uporablja kot sprožilec za emocionalno povezavo med vrstama.

Hibridna družina je še en izmed projektov v seriji K-9_topologije. V tem performansu je Smrekarjeva vzgajala kužka. Z dva in pol meseca trajajočim fiziološkim treningom je dosegla, da se je v nje- 
nih prsih začelo proizvajati mleko. Umetnica o tem procesu govori kot o procesu postajanja, postajanja žival, postajanja ženska in postajanja (druga) mati. Globoko je zasidrana v svoje izkustvo na začetku 3. tisočletja, ko je, kot je zapisala v svojem blogu, "liberalni kapitalizem končno globoko zarezal v novorojeno slovensko gospodarstvo": njena starša sta izgubila podjetje, hišo, avtomobile, gozdove, travnike in vinograde, njen oče pa je naredil samomor. Sama je našla svoj način upora, ki se izraža v tem, da se podvrže "odnosu pasje-človeškega sorodstva kot radikalnemu intimnemu dejanju "vrnitve domov"'.

$\mathrm{V}$ pričujočem prispevku je proces postajanja mati analiziran $\mathrm{V}$ povezavi s procesom postajanja žival. Še več, proces postajanja (druga) mati je še posebno pod drobnogledom glede na enotnost mati-in-otrok, z uporabo pojma Umwelt in heglovske, eksistencialistične feministične in post-strukturalistične diskusije identitete in razlikovanja. Proces postajanja (druga) mati je na koncu preučen še kot biopolitična izjava ali intervencija z investicijo umetničinega telesa. Njegov namen je ponovno pridobiti pozicijo moči, torej izvesti dejanje upora bio-moči - vaja moči na telesu in skozenj.

Ključne besede: biopolitika, drugo, Maja Smrekar, bio-moč, uprizoritvena umetnost, K-9_topologija, Hibridna družina

\section{* * * *}

With the series K-9_topology, Maja Smrekar is challenging anthropocentrism by linking biology and culture, in particular addressing interaction between human and animal species. The artist builds upon the recent scientific findings that it is not only the dog species that has been domesticated; the domestication that took place during evolution is to be considered mutual. Not only has the dog been 
mastered by the human, but dogs have had an active role in "using" the human species for a more comfortable survival as well. Both species coexist. In the project Ecce Canis Maja Smrekar built upon the sense of smell as an interface used to trigger the emotional connection between the species.

Hybrid Family is another project in the K-9_topology series. In this performance Smrekar nurtured a puppy. By submitting herself to two and a half months of physiological training, she achieved milk production in her breasts. The artist refers to this process as to the process of becoming, of becoming-animal, becoming-woman and becoming $\mathrm{m}$ (Other). The project is deeply rooted in her own experience, as she writes in her blog. At the beginning of the $3^{\text {rd }}$ millennium, "liberal capitalism finally struck hard into the newborn Slovenian economy", so her parents lost their business, house, cars, forests, meadows and vineyards, and her father committed suicide. In this regard Hybrid Family is her way of resisting the neoliberal power over the bodies and lives of people.

\section{Becoming mother}

Maja Smrekar bought a young puppy, which had been taken away from its primary dog-mother, and adopted the role of its new parent. In addition to ensuring a new home for the puppy, as any ordinary dog keeper would, this new parent ensured its nurture in the most literal sense possible, by breast-feeding it. Let us consider the significance of this act more carefully.

With breast-feeding the puppy and the artist connect biologically, if biologically means through and with investing their own bodies. The artist "hunts nature". She has not only become a sort of social parent to the puppy, ensuring care and protection. Becom-

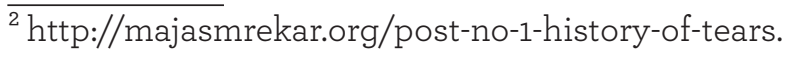


ing the breast-feeding "parent" to the puppy puts this human dog keeper in a corporeal relationship with the dog.

"Naturally" milk is produced within the exchange process between mother and child; the production is realised by the mother but evoked by the child. The mother's capacity to produce milk is enabled only by the child's evocation. The production of milk by the woman's body is thus a process that originates from the tight connection between the mother and the child, or the unity mother-child.

Breast-feeding is a process significant for the mother-child formation, in which the two are mingled together. Julia Kristeva ascertains that in this phase the child does not yet have a narcissist attitude, which only develops after the intervention of the third, who becomes the object of the mother's desire. The third breaks apart the dyad. According to psychoanalysis, this moment signifies the beginning of the process of autonomisation or the formation of the self. $^{3}$ In our case we are not paying attention to the moment at which the formation of the self begins, but to the moment which is originally performed here, that is, the moment at which the motherchild formation is established. The project thus establishes the situation before the moment of quitting the breast-feeding, in which the boy is protected against regret that he is no longer a breastfeeding baby or a girl, as ascertained by Simone de Beauvoir, since from then on he will embody his transcendence and his arrogant sovereignty in his sex. ${ }^{4}$ If this moment signifies the becoming of the first or the second sex, to paraphrase de Beauvoir, the project performs a "reverse" process of becoming: of becoming the breastfeeding mother for the artist and of becoming the human breastfed baby for the dog.

\footnotetext{
${ }^{3}$ Kristeva, 1987.

${ }^{4}$ Beauvoir, 2010.
} 
Mother and child are in this formation of breast-feeding mingled to such a degree that they exist as an entity. Rather than the other of the child's self, the mother is a part of the child's own subjectivity, of the child's own self.

This moment of unity could also be examined with a reference to the notion of the Umwelt, introduced by Jakob von Uexküll. ${ }^{5}$ The early $2 \mathrm{O}^{\text {th }}$ century zoologist and one of the founders of ecology, Jakob von Uexküll, examines the notion of the environment that is bound to an animal. For Uexküll animals don't experience the same world and time. The bee, the tick and the fly that we observe don't move in the same world or share the same world with us, the observers. Each Umwelt is a closed unity within itself.

For Uexküll there exists also die Umgebung, a rather objective environment which, however, changes according to one's perspective, since there is no objective space per se: there is only a forestfor-a-woodcutter, a forest-for-a-botanic, a forest-for-a-wanderer, etc. Uexküll does not find much interest in the notion of die Umgebung, but offers a very interesting examination of the structure of die Umwelt, in which the world and the animal are intrinsically or existentially linked.

Uexküll takes into consideration the case of a tick. The fundamental aspects of the structure of die Umwelt, the environments that are valid for all animals, can be derived from the example of the tick. Out of the egg crawls a not yet fully developed little animal, but even in this state it can already ambush cold-blooded animals such as lizards, for which it lies in wait. Once the female has copulated, the eyeless and deaf creature finds its way to a warm-blooded animal, from which it pumps a stream of warm blood. Uexküll ascertains that the tick uses the sense of smell and has no sense of

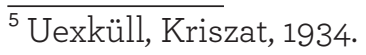


taste. It takes in any liquid, so long as it has the right temperature. For the tick it is existentially relevant to get the meal: after getting it, it will fall to the ground, lay its eggs and die. The tick gets into a "functional cycle as a subject and the mammal as its object".

In die Umwelt there are carriers of characteristics or significance; in semiology these would be marks [Merkmalträger], which are also carriers of meaning [Bedeutungsträger]. These carriers are all that interests an animal. An animal has receptive organs that are designed to perceive the mark [Merkorgan] and to react to it [Wirkorgan].

Uexküll believes that his explanation of the subject - object interconnectedness in die Umwelt has finally connected biology to Kant's philosophy by emphasising the decisive role of the subject, because there can be no time and no space without a living subject. ${ }^{7}$

By analogy with Uexküll we can postulate that in the case of the child and the mother, the child undertakes a role similar to the tick's. The functional cycle of breast-feeding makes the mother the object of the child in the sense that she is required for the child to survive, she is the child's host, the nourisher, the food, the existential expansion of the parasite child. Together they form this significant environment, die Umwelt, which is a closed unity within itself. We, not being part of it, don't share their world. And there is one significant conclusion that we have to formulate at this moment: there is no mother per se, there is no objective mother, the mother is the mother-for-the-child. The fact that the artist voluntarily undertakes the "objectification" of herself for the puppy by becoming motherfor-the-puppy though breast-feeding, as well as through becoming the puppy's social parent, opens up a new dimension of the project.

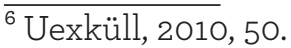

${ }^{7}$ Ibid., 52.
} 
One should not forget that the dog keeper is legally responsible for ensuring proper care for the animal. The role of the caretaker is somehow similar to the role of the parent. However, the dog is considered the dog keeper's property, an object with an ability to suffer, which is why suffering may not be caused. Yet the punishment for the violation of a child's or a puppy's rights tells the most about the hierarchical difference between human and animal, as agreed upon in a given society. The difference between the two species has been recognised within historical materialism, as ascertained by de Beauvoir, which ensured a relevant recognition that "[h] umanity is not an animal species; it is a historical reality". If Maja Smrekar is becoming mother-for-the-puppy, this makes up a significant dimension of the process of becoming, in which she is simultaneously becoming an animal-mother. With objectifying herself for the dog, she is resisting the policy by which domestic animals are considered proprietorial objects of humans. The hierarchical differentiation of human and animal species is here subverted.

\section{Becoming animal, becoming other}

Saying that one is becoming an animal seems senseless since man is an animal, a speaking animal, if we agree with Jacques Derrida. ${ }^{9}$

For Martin Heidegger, however, there exists a difference between animal and human and stone; it lies in the relation of each of them to the world: "the stone is worldless [weltlos]; the animal is poor in the world [weltarm]; man is world-forming [weltbildend]." The origin of Heidegger's consideration of the relation between the being and the world is to be found in Uexküll: what Uexküll defined as marks or carriers of meaning, Heidegger calls disinhibitors, and

\footnotetext{
$\overline{{ }^{8} \text { Beauvoir, } 87 .}$

${ }^{9}$ Derrida, 2008.
} 
what Uexküll defined as die Umwelt, Heidegger calls the disinhibiting ring. Heidegger examines the relationship of the animal to its disinhibiting ring further in order to define what he called the "poverty in the world" characteristic of animals. Heidegger differentiates between animal existence in the world and the mode of the human world. The mode of existence proper to an animal is signified in its relation with the disinhibitor - it is in a state of captivation. As an example of captivation Heidegger presents the case of a bee described already by Uexküll. A bee, placed in front of a cup full of honey, begins to suck it, then its abdomen is cut away, yet the bee happily continues to suck while the honey visibly streams out of its open abdomen. The animal is captivated, stunned, but also taken away, blocked [benommen], as well as taken in, absorbed [eingenommen]. The animal is essentially captivated and wholly absorbed in its own disinhibitor. It cannot truly act in relation to it, it can only behave. ${ }^{10}$

The animal is being-alongside-itself: the animal does not recognise the situation, the bee does not recognise the presence of too much honey neither the absence of its abdomen. It is taken by [hingenommen] the food. "This being taken is only possible where there is an instinctive 'towards ...' [treibhaftes Hin-zu]. Yet this being taken in such a drivenness also excludes the possibility of any recognition of any being-present-at-hand [Vorhandensein]. It is precisely being taken by its food that prevents the animal from taking up a position over and against [sich gegenüberzustellen] this food."11

The baby is taken by the mother's milk. When the animal comes in contact with its disinhibitor, it gets taken by [hingenommen] the

\footnotetext{
${ }^{10}$ Agamben, 2004, 52.

${ }^{11}$ Heidegger, 1995, 263; original in Heidegger, Gesamtausgabe, vols. 2930, Die Grundbegriffe der Metaphysik. Welt-Endlichkeit-Einsamkeit, Frankfurt am Main: Klostermann, 1983, p. 383.
} 
food, it is captivated, because the "very possibility of apprehending something as something is withheld [genommen] from the animal, and it is withheld from it not merely here and now, but withheld in the sense that it is "not given at all". ${ }^{12}$ We can draw an analogy with the captivation of the animal and the breast-feeding child. The breast-feeding baby gets into a disinhibiting ring. The baby is driven toward the breast. It gets into instinctive drivenness "toward". Being taken by the milk prevents the child from taking up a position over the milk or apprehending something as something. In this case, however, the subject experiencing the "poverty in the world" is not the animal as in the case discussed by Heidegger, but the child, which is a pre-state of human being.

The captivated subject, the breast-feeding child, does not, according to Heidegger's theory, fulfil the criteria for a human being. The difference between man and animal lies in the human capability to act in relation to the world or to act against it, according to Heidegger. It would not be correct to say that this child is becoming human through the process of breast-feeding or this performance. Recalling Derrida saying that man is a speaking animal, let us reflect upon the communication aspect. Uexküll refers to the decisive role of the subject expounded by Kant when conceptualising the notion of die Umwelt to show how space and time depend on the subject, the animal in our case. Kant introduces the notion of existence of things for the subject. So how does the baby exist for itself? The environment, time and space are formed according to the subject, they exist for the subject. But as a being in the state of captivation, the child is not capable of apprehending something as something. Accordingly, it is not capable of apprehending itself. The same holds true for the animal. There is a certain difference

${ }^{12}$ Ibid., 253; original, 269. 
between the baby and the grown-up. If man is a speaking animal and other animals are not speaking, the baby is a non-speaking animal, an animal as all other non-speaking animals. The mother, on the contrary, is a speaking animal.

One might say that the mother is capable of reaching the state of being-for-herself. She is thus a conscious being, and it is consciousness that makes the difference between human and animal. On the other hand, Jean-Luc Nancy disagrees that consciousness is the criterion and claims there is no difference between man and animal. There is no consciousness, but there is exchange. ${ }^{13}$

Let us consider the breast-feeding performance as a communication event. Jean-Luc Nancy recalls Edmund Husserl's reflection upon the silent voice of the self, talking to itself, listening to itself. The self communicates with the self. One aims to be present to oneself. Yet to see oneself can only happen if there is a difference between presence one and presence two. There is an "Augenblick", a moment, it takes a while. The self starts to go to the self, but the self will never find itself. There is a différance at work. With this term Jacques Derrida refers to the double meaning implied in its root: the French verb différer means to be different from or to delay something. The delay of the différance is an infinite delay. To be becomes suspended. It is a continuous, never ending process of becoming.

If the baby has no capability to apprehend itself as itself, to be present to itself, it does not even start to go to the self. The mother, by contrast, has the ability to aim to be present to herself as the mother. Yet this to be, the identity, is suspended. The mother enters the continuous process of becoming mother.

\footnotetext{
${ }^{13}$ Jean-Luc Nancy in a Ph.D. seminar for the Humanities program, Alma Mater Europaea - Institutum Studiorum Humanitatis in collaboration with the Global Center for Advanced Studies, 30 ${ }^{\text {th }}$ August 2016.
} 
Considering the existence of an identity, Hegel introduced the notion of an other. The relationship between the two, the mother and the baby, is essential for the establishment of their identities. It is the baby that makes the mother the mother. According to Hegel, something is existence, determined by its relationship to others: "[s]omething is a determinate existence, this something is in relationship to others, and also to a perceiver among these others." ${ }^{\text {14 }}$

Identity is being established not essentially, but through a differentiation process in relation to that which something is not, i.e. through negative relational defining. Something is defined through relations and differentiations, negations (and confirmations).

Furthermore, for Hegel, something is also becoming. The two moments are not those of abstract being and nothing, but an existence, something, and another existence, which is the negative of something. "The other moment is equally an existent, but determined as the negative of something - an other. As becoming, something is a transition, the moments of which are themselves something, and for that reason it is an alteration - a becoming that has already become concrete." 15

With breast-feeding the puppy, the artist positions herself in a kinship relationship with the dog. She enters a process of differentiation and of becoming the negative of herself as a speaking animal, that is, as a non-speaking animal. At the same time the puppy enters a process of becoming human. Humanity enters its differentiating identity, the identity of a non-speaking animal, which has the speaking animal as its other. This equalisation of the two processes of becoming is significant for the artist. Agamben's finding that " $[t]$ he total humanization of the animal coin-

\footnotetext{
$\overline{{ }^{14} \text { Hegel, 2010, } 64 .}$

${ }^{15}$ Ibid., 90.
} 
cides with a total animalization of man" ${ }^{\text {16 }}$ is a relevant reference in the K-9_topology. ${ }^{17}$

In short, we will focus upon the political implications of this equalisation. But first we need to shed light on the artist's struggle for de-hierarchisation, since the two species do not enjoy political equality. The original positioning of the artist lies in making herself a disinhibitor for the puppy. In this disinhibiting ring she does not take over the "higher" state of being as regards the relation to the world, but a "lower" one, as far as one can gather a hierarchical positioning of the human, animal and stone in Heidegger. She enters a transsubstantiation process of becoming a "defined" being, an animal, as Heidegger comprehended the animal. At the same time the animal becomes "privileged" with its transition to the human.

Becoming a non-speaking animal is, however, at work also in the mother-child formation through breastfeeding, if we infer from Heidegger that the baby is a "defined" being as well as other animals. It is the state and the relation to the disinhibitor that defines the being as "defined" or "non-defined". The "defined" being is not in a state in which the subject would be able to apprehend something as something or itself as itself, or in which it would aim to reach a comprehension of itself. In this state the subject surrenders to the instinctive drivenness "toward", it is the state of captivation. With putting herself in this state, Maja Smrekar can discard the "privilege" of the human to be a "non-defined" being. As this project demonstrates, the mother is not a mere host that harbours the parasite, the breast-feeder: rather, she is captivated in her own turn by the breast-feeder in this functional cycle. The one who gives suck is dependent on sucking, as the whole process of breast-feeding is

\footnotetext{
${ }^{16}$ Agamben, 77.

${ }^{17}$ <http://majasmrekar.org/k-9_topology> 1. 11. 2016
} 
dependent on the breast-feeder. The existence of this breast-feeding Umwelt is established on breast-feeding, since without sucking there is no milk. Therefore, it is relevant to conceive the Umwelt of the breast-feeding mother and the child, as well as the Umwelt of the artist and the puppy, as an exchange circuit.

For Maja Smrekar this physiological captivation is of extreme importance. It becomes her means of resistance: "Becoming (- ani$\mathrm{mal}$ ) is a molecular process: in my case the molecular process of my pituitary glands being so much triggered by systematic breastpumping, they would get connected with hormone prolactin to accumulate milk in my body. As a side effect of that triggering, hormone oxytocine increases, which evokes empathy." ${ }^{18}$

\section{Biopolitical resistance: becoming bare life}

"I hunt nature and culture hunts me," another K-9_topology performance. Aiming at becoming "nature" is aiming at escaping culture. Maja Smrekar aims at becoming "zoē", bare life, the domain once reserved only for animals. But what can we say today of the distinction between zoē and bios? According to Giorgio Agamben, the anthropological machine produced humanitas by de-ciding every time between man and animal. There is a "total management" of biological life at work today, that is, of the very animality of man. Humanity "has taken upon itself the mandate of the total management of its own animality". ${ }^{20}$

Maja Smrekar responds to the situation in which bio-power is being exercised on and through the bodies, as ascertained by Michel Foucault. "As an artist I feel I need to use my own body (and bodies

$\overline{18}$ <http://majasmrekar.org/post-no-2-involution-of-m-mother> 19. 10. 2016.

${ }^{19}$ The title of another Maja Smrekar's performance with wolves.

${ }^{20}$ Agamben, 77. 
of my dogs) to re-gain the position of power. To re-gain my body. Our bodies."21 The project of becoming (m)Other is to be comprehended as a biopolitical statement or intervention with the investment of artist's body for the purpose of re-gaining the position of power and her own animality, i.e. as an act of resistance to bio-power.

Her artistic gesture is additionally to be read as a response to neoliberal capitalism: "The global economy threatens to homogenize people by means of the lowest common denominator - the ability to consume." The artist feels the urge to resist by using her own economy of emotions: "Therefore I am submitting myself to the dog-human kinship relationship as a radical intimate action of 'returning home.."22

\section{Bibliography}

AGAMBEN, G. (2004): Open. Man and Animal, trans. by Kevin Attell, Stanford University Press, Stanford.

BEAUVOIR, S. de (2010): The Second Sex, trans. by Constance Borde and Sheila Malovany-Chevallier, Vintage Books (Random House), New York.

DERRIDA, J. (2008): The Animal that Therefore I Am, trans. by David Wills, Fordham University Press, New York.

HEGEL, G. W. F. (2010): The Science of Logic, trans. by George di Giovanni, Cambridge University Press, Cambridge. HEIDEGGER, M. (1995): The Fundamental Concepts of Metaphysics: World, Finitude, Solitude, trans. William McNeill and Nicholar Walker, Indiana University Press, Bloomington.

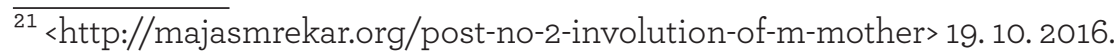
${ }^{22}<$ http://majasmrekar.org/blog> 19. 10. 2016.
} 
KRISTEVA, J. (1987): Tales of Love, New York: Columbia University Press.

UEXKÜLL, J. von, KRISZAT, G. (1934): Streifzüge durch die Umwelten von Tieren und Menschen, Springer, Berlin.

UEXKÜLL, J. von (2010): A Foray into the Worlds of Animals and Humans, trans. by Joseph D. O’Neil, University of Minnesota Press, Minneapolis, London.

\section{Webology}

http://majasmrekar.org/blog

http://majasmrekar.org/k-9_topology

http://majasmrekar.org/post-no-1-history-of-tears

http://majasmrekar.org/post-no-2-involution-of-m-mother 